\title{
Sterile Clay Pozzolans from Phosphate Mining
}

\author{
José Afonso de Matos Neto ${ }^{a}$, Domingos Sávio de Resende ${ }^{a}$, João Trajano da Silva Neto ${ }^{b}$, \\ Antônio Maria Claret de Gouveia ${ }^{b}$, Maria Teresa Paulino de Aguilar ${ }^{c}$, \\ Augusto Cesar da Silva Bezerra ${ }^{a *}$ \\ ${ }^{a}$ Centro Federal de Educação Tecnológica de Minas Gerais, Av. Amazonas, 5253, \\ Nova Suiça, CEP 30421-169, Belo Horizonte, MG, Brazil \\ ${ }^{b}$ Universidade Federal de Ouro Preto - UFOP, Campus Universitário, \\ Morro do Cruzeiro, s/n ${ }^{\circ}$, CEP 35400-000, Ouro Preto, MG, Brazil \\ ${ }^{c}$ Universidade Federal de Minas Gerais - UFMG, Av. Antônio Carlos, 6627, Pampulha, \\ CEP 31270-901, Belo Horizonte, MG, Brazil
}

Received: December 14, 2014; Revised: October 10, 2015

\begin{abstract}
The work presents the characterization of clays from sterile mining of the concentrated phosphatic materials of Araxá in Minas Gerais as pozzolanic materials. Three clays of distinct tones, namely, yellow (YC), red (RC), and intermediate (IC) clays, were used at different levels of excavation depth. The clays were calcined at three temperatures $\left(680,760\right.$, and $\left.840^{\circ} \mathrm{C}\right)$ in a muffle-type electric oven. The pozzolanic activity levels of the calcined clays was measured through the conductivity change in saturated $\mathrm{Ca}(\mathrm{OH})_{2}$ solutions and also from the result of the compressive failure load achieved by mortars with $35 \%$ of the Portland cement replaced with the calcined material. The results indicated that the calcined clays showed a high level of pozzolanic activity and can be used as a partial substitute for Portland cement, thus suggesting the possibility of recovering this sterile material.
\end{abstract}

Keywords: clays, pozzolanic activity, sustainability

\section{Introduction}

In the state of Minas Gerais, there is a large concentration of mining activities. The Meso-region of Alto Parnaíba and Triângulo Mineiro, has three mining companies: two phosphate extractors and a pyrochlore extractor. Phosphates have major applications in fertilizer production, whereas pyrochlore is utilized for the production of metallic niobium and its derivatives.

Micro-region of Araxá has two mining complexes: Barreiro complex and Tapira complex. The Barreiro complex is located in the Araxá-MG municipality and currently has two mining companies. Tapira Mining Complex (TMC) is located in Tapira-MG municipality, which is about $35 \mathrm{~km}$ from Araxá city. According to Santos et al. ${ }^{1}$, the activities of the complex occupy an area of approximately $78 \times 10^{6} \mathrm{~m}^{2}$ with an annual production of concentrate (in terms of $\mathrm{P}_{2} \mathrm{O}_{5}$ ) around $1.6 \times 10^{6}$ tonnes / year.

With the growth in fertilizers, the proportionate increase in production demand has increased environmental liabilities represented by materials considered waste or sterile, which are currently packed in sludge containment dams or in huge dams that increasingly require large areas for disposal. The Tapira Mining Complex industrial process generates waste at around $85 \%$ of the feed mass in the concentration plant ${ }^{1}$.

Given the importance of cement to world development, concrete is the second most consumed product in the world and is second only to water. Portland cement-based products

*e-mail: augustobezerra@des.cefetmg.br are known to have great potential for promoting economically viable solutions for the immobilization of industrial waste, thus contributing to the sustainable development of industrial activities.

Therefore, this work will contribute to the study of an industrial waste, primarily consisting of clay. This work will investigate the possibility that these clays, when thermally activated, possess considerable pozzolanic potential to be used as raw materials to partially replace Portland cement.

\section{Material and Methods}

\subsection{Materials}

The research material covered in this study was the sterile material generated in TMC. By analysing the process of this mining complex, which comprises an area of $35 \mathrm{~km}^{2}$ with a large coverage usually with an average depth of $30 \mathrm{~m}$ predominantly of clay soil corresponding to sterile area, with different physical and textural characteristics, presenting a red and yellowish tint granular appearance ${ }^{1}$. The clays were collected at three different levels in the concentrated phosphatic extraction mine (TMC). The collection points were identified with the aid of a GPS (GARMIN - GPS 12) and are listed in Table 1.

The binder used was Portland cement with class 32-MPa slag compound (CPII E 32). Portland cement was selected because its composition does not present pozzolanic additions 
and because it is the most commonly available type in markets in the region where this research was conducted. For manufacturing the cement composites, natural standardized sand was used as the fine aggregate.

\subsection{Methods}

The sterile clay was naturally collected in the TMC mine and stored in plastic bags containing approximately $50 \mathrm{~kg}$ of each material sample. In Figure 1, it is possible to observe the surface layers of the TMC mine. The reddish soil is called red clay (RC), and the yellow soil below the red clay is known as yellow clay (YC). Between the sterile zone (yellow-red soil) and the mineralization zone (grey soil), intermediate soil can be observed, which is known as intermediate clay (IC) in this work.

After collecting the material, the clay was dried and homogenized in laboratory. The material was divided into four parts to obtain a sufficient amount of the sample. The samples were prepared for the characterization tests, and the material was characterized through moisture tests, by particle size, and by determining the amount of liquid and plasticity. Then, the material underwent processing by grinding and screening through a sieve with an aperture of $0.075 \mathrm{~mm}$.

The calcination was performed in a muffle-type electric oven with a controlled temperature up to $1200^{\circ} \mathrm{C}$. The heating chamber had internal dimensions of $200 \times 150 \times 150 \mathrm{~mm}^{3}$ with $3.5-\mathrm{kW}$ power and a $220-\mathrm{V}$ power supply. The material was placed in porcelain crucibles and subjected to calcination

Table 1. Geographic location of samples.

\begin{tabular}{cccc}
\hline Clay type & Latitude & Longitude & Altitude \\
\hline Yellow (YC) & $19^{\circ} 53^{\prime} 20.7^{\prime} \mathrm{S}$ & $46^{\circ} 51^{\prime} 0.36^{\prime} \mathrm{W}$ & $1315 \mathrm{~m}$ \\
Intermediate (IC) & $19^{\circ} 53^{\prime} 19.2^{\prime} \mathrm{S}$ & $46^{\circ} 51^{\prime} 02.0^{\prime \prime} \mathrm{W}$ & $1290 \mathrm{~m}$ \\
Red (RC) & $19^{\circ} 53^{\prime} 50.5^{\prime} \mathrm{S}$ & $46^{\circ} 51^{\prime} 24.66^{\prime} \mathrm{W}$ & $1354 \mathrm{~m}$ \\
\hline
\end{tabular}

temperature conditions at three different temperatures and at two different time intervals, as shown in Table 2 . All tests occurred at a heating rate of $25^{\circ} \mathrm{C} / \mathrm{min}$.

After processing, the materials were physic-chemically and morphologically characterized. Physical characterization of the processed clays was performed using specific mass tests and loss on ignition. Chemical characterization and the degree of crystallinity were determined by X-ray fluorescence spectroscopy testing (EDX) and X-ray diffraction (XRD). The morphology of the clays was analysed macroscopically using digital camera photographs and microscopically using scanning electron microscopy (SEM). The thermal behaviour of the processed clays was analysed through differential thermal analysis (DTA) and thermogravimetry (TGA) tests.

After characterizing the clays, their pozzolanic activity was assessed using electrical conductivity in saturated calcium hydroxide ${ }^{2}$, and the pozzolanic activity index with cement was determined according to NBR $5752^{3}$ methods.

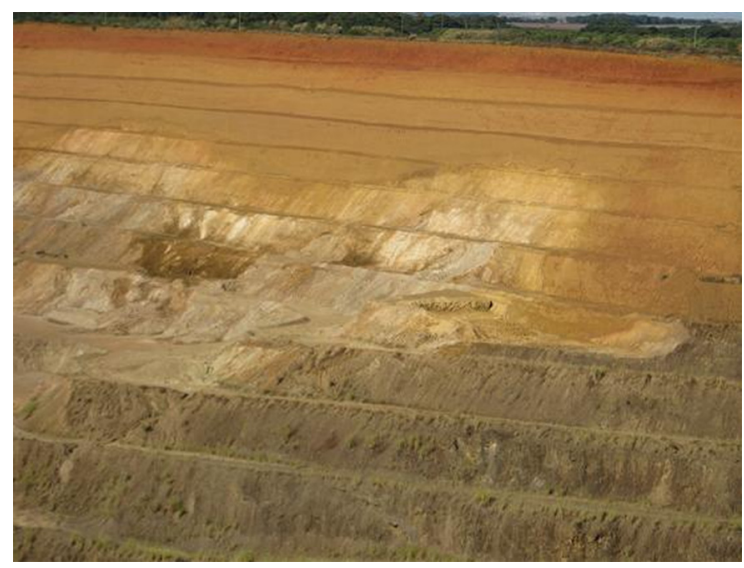

Figure 1. Front view of the TMC phosphate mine.

Table 2. Calcination conditions.

\begin{tabular}{|c|c|c|c|}
\hline Sample identification & Clay type & Temperature $\left({ }^{\circ} \mathrm{C}\right)$ & Burn off time (min.) \\
\hline YC.680.60 & Yellow Clay & 680 & 60 \\
\hline IC.680.60 & Intermediate Clay & 680 & 60 \\
\hline RC.680.60 & Red Clay & 680 & 60 \\
\hline YC.760.60 & Yellow Clay & 760 & 60 \\
\hline IC.760.60 & Intermediate Clay & 760 & 60 \\
\hline RC.760.60 & Red Clay & 760 & 60 \\
\hline YC. 840.60 & Yellow Clay & 840 & 60 \\
\hline IC. 840.60 & Intermediate Clay & 840 & 60 \\
\hline RC. 840.60 & Red Clay & 840 & 60 \\
\hline YC.680.120 & Yellow Clay & 680 & 120 \\
\hline IC. 680.120 & Intermediate Clay & 680 & 120 \\
\hline RC. 680.120 & Red Clay & 680 & 120 \\
\hline YC.760.120 & Yellow Clay & 760 & 120 \\
\hline IC.760.120 & Intermediate Clay & 760 & 120 \\
\hline RC.760.120 & Red Clay & 760 & 120 \\
\hline YC. 840.120 & Yellow Clay & 840 & 120 \\
\hline IC. 840.120 & Intermediate Clay & 840 & 120 \\
\hline RC. 840.120 & Red Clay & 840 & 120 \\
\hline
\end{tabular}




\section{Results}

Table 3 presents the results of the clay characterization. The moisture content of the clays may be associated with the hygroscopic moisture, acquired at different depths at the fresh sample collection points. This could explain why IC has the highest moisture in ambient conditions, given its deeper location in the excavation, which is close to the groundwater. On the other hand, $\mathrm{RC}$ has lower moisture content due to its location in more superficial layers. Correlating the moisture content results with the specific mass and the percentage of particles larger than $38 \mu \mathrm{m}$, the moisture in the clays showed a different behaviour than expected because dense materials with smaller particle sizes commonly have higher levels of humidity.

As to specific masses, one can assume with respect to the values found, these being proportional to particle sizes. In other words, smaller grain diameters have lower specific mass. Thus, in order of increasing specific mass, we find RC $(2.727)<\mathrm{YC}(2.871)<\mathrm{IC}(3.046) \mathrm{in} \mathrm{g} / \mathrm{cm}^{3}$. Regarding the fineness of the particles passing through sieve 0.038 (\#400), we found that the percentage retained had the same order of magnitude of RC (4.4) < YC (8.6) < IC (16.25).

Of the tested clays, the different levels of loss to fire are primarily due to the loss of structurally bound water in the form of hydroxyl groups $(\mathrm{OH})$ and due to the volatilization of organic matter. In the case of $\mathrm{RC}$, the volatilization of organic matter presented a more significant number.

The results shown in Table 3 indicate that the YC-IC clays can be classified as moderately plastic $(7<\mathrm{PI}<15)$, while $\mathrm{RC}$ is considered to be highly plastic clay. It is noteworthy that all clays tested meet the established maximum liquid limit of $45 \%$ and exceed the established maximum of $18 \%$ for the plasticity index. The result of the retraction test showed no transverse cracks in the central portion of the sample that exceeded the threshold of $2.0 \mathrm{~cm}$. The observed cracks were less than $1.0 \mathrm{~cm}$, which confirms the absence of expansive clay, and agrees with plasticity results ${ }^{4}$.

Table 4 shows the results obtained by chemical analysis of the clays using X-ray fluorescence, which is expressed in terms of pure elements. The main constituent elements of the studied clays are iron $(\mathrm{Fe})$, with percentages ranging from

Table 3. Characterization of clays.

\begin{tabular}{cccc}
\hline Characterization & YC & \multicolumn{1}{c}{ IC } & RC \\
\hline Moisture content (\%) & 1.57 & 2.55 & 1.44 \\
Specific mass $\left(\mathrm{g} / \mathrm{cm}^{3}\right)$ & 2.871 & 3.046 & 2.727 \\
Particles larger than $38 \mu \mathrm{m}(\%)$ & 8.60 & 16.25 & 4.40 \\
Loss to fire (\%) & 13.00 & 9.00 & 21.00 \\
Liquidity limit (\%) & 44.00 & 39.00 & 53.00 \\
Plasticity limit (\%) & 29.00 & 26.00 & 34.00 \\
Plasticity index (\%) & 15.00 & 13.00 & 19.00 \\
\hline
\end{tabular}

39.78 to $45.44 \%$, aluminium (Al), varying from 10.05 to $37.77 \%$ and silicon ( $\mathrm{Si}$ ), varying from 13.03 to $21.21 \%$. These results confirm the possibility of these clays presenting some degree of pozzolanicity. Studies report that alumina and iron oxide are the predominant components of argillaceous materials, but the relative amounts of $\mathrm{SiO}_{2}$ and $\mathrm{Na}_{2} \mathrm{O}$ (or $\mathrm{NaOH}$ ) are also relevant ${ }^{5}$. In low levels, the clays contain barium $(\mathrm{Ba})$, calcium $(\mathrm{Ca})$, phosphorus $(\mathrm{P})$, potassium $(\mathrm{K})$, and titanium (Ti). In addition, the results showed traces of zinc $(\mathrm{Zn})$, manganese $(\mathrm{Mn})$, zirconium $(\mathrm{Zr})$, copper $(\mathrm{Cu})$, niobium $(\mathrm{Nb})$, strontium (Sr), vanadium (V), yttrium (Y), and cerium (Ce).

When compared with other clays, YC has a high $\mathrm{Si}$ content, while RC has higher aluminium content, which is an indicative of the existence of a higher percentage of clay minerals. High Fe levels in clays are sufficient to ensure the reddish colour after burn off. The ratio of silica to alumina is an indicative parameter of the amount of present clay minerals. Thus, a lower silica/alumina quotient indicates a higher content of clay minerals present and greater plasticity. These results could justify the higher plasticity index of RC clay as well as the occurrence of a high iron content, which is responsible for the red colour before and after burn off.

The degree of crystallinity was qualitatively evaluated by X-ray diffraction. In Figure 2, the X-ray diffraction results of the clays are presented. In the sample diffractograms, the presence of several peaks of crystalline materials is observed, such as kaolinite, goethite, anatase, apatite, and gibbsite. These results are consistent with those reported in the application study of red mud residue from bauxite processing for use as raw material in clay-based products ${ }^{6}$. The spectra are consistent with the results presented in the X-ray Fluorescence Spectroscopy test that shows the prevalence of elements such as $\mathrm{Al}, \mathrm{Fe}, \mathrm{Si}, \mathrm{Ti}$, and $\mathrm{P}$.

In the YC XRD data, we observe kaolinite, goethite, and apatite with sharp, intense reflections at angles of $12.26,21.34$, and $36.9(2 \theta)$, respectively, and we observe

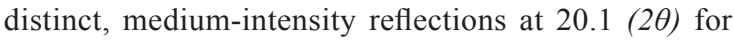
kaolinite and $30.26(2 \theta)$ for apatite. The IC XRD data also features kaolinite, goethite, and anatase with sharp, high intensity reflections at angles of $12.34,21.24$, and 25.36 (20), respectively. Regarding the RC XRD data, gibbsite stands out with a sharp, high intensity peak at 18.27 (20). Other characteristics of kaolinite are observed with lower intensity at angles of $12.26,20.25$, and $24.78(2 \theta)$, and we find a low intensity goethite reflection at $21.4(2 \theta)$.

Table 5 shows the measured weight loss after the calcination process. In this process, 20-g samples were passed through a sieve with an opening of $0.075 \mathrm{~mm}$ (\#200) in established temperature and time conditions. It is observed that RC showed the highest percentage of mass loss (14-15.3\%), while YC lost around 6.6-7.3\%, and IC showed the smallest loss of $2.45-3.15 \%$. These values are directly correlated to loss values during burn off. The calcined

Table 4. EDX analysis of the clay chemical composition.

\begin{tabular}{cccccccccccccccc}
\hline & $\mathbf{A l}$ & $\mathbf{B a}$ & $\mathbf{C a}$ & $\mathbf{C e}$ & $\mathbf{C u}$ & $\mathbf{F e}$ & $\mathbf{K}$ & $\mathbf{M n}$ & $\mathbf{N b}$ & $\mathbf{P}$ & $\mathbf{S i}$ & $\mathbf{S r}$ & $\mathbf{T i}$ & $\mathbf{V}$ & $\mathbf{Z r}$ \\
\hline $\mathbf{Y C}$ & 23.1 & 1.2 & 1.1 & 0.6 & 0.1 & 40.8 & 0.6 & 0.3 & 0.3 & 3.0 & 21.2 & 1.0 & 6.0 & - & 0.7 \\
$\mathbf{I C}$ & 10.1 & 1.3 & 8.3 & 0.7 & 0.1 & 45.4 & 2.3 & 0.9 & 0.4 & 6.0 & 14.2 & 0.8 & 8.1 & - & 1.3 \\
$\mathbf{R C}$ & 37.8 & 3.7 & 0.2 & 0.6 & - & 39.8 & - & - & 0.1 & - & 13.0 & 0.2 & 3.4 & 0.8 & 0.4 \\
\hline
\end{tabular}


samples were used to assess the level of pozzolanic activity through electrical conductivity in solution. The results of the measurements are presented in Table 4. By observing the difference in conductivity, most of the calcined clays have a high level of activity with calcium hydroxide solution, indicating that these clays can be considered to have a high pozzolanic activity index; however, IC.840 clays (60-120) are considered moderate.

Figure 3 shows the results of the pozzolanic activity index test using the compressive strength of proof-bodies

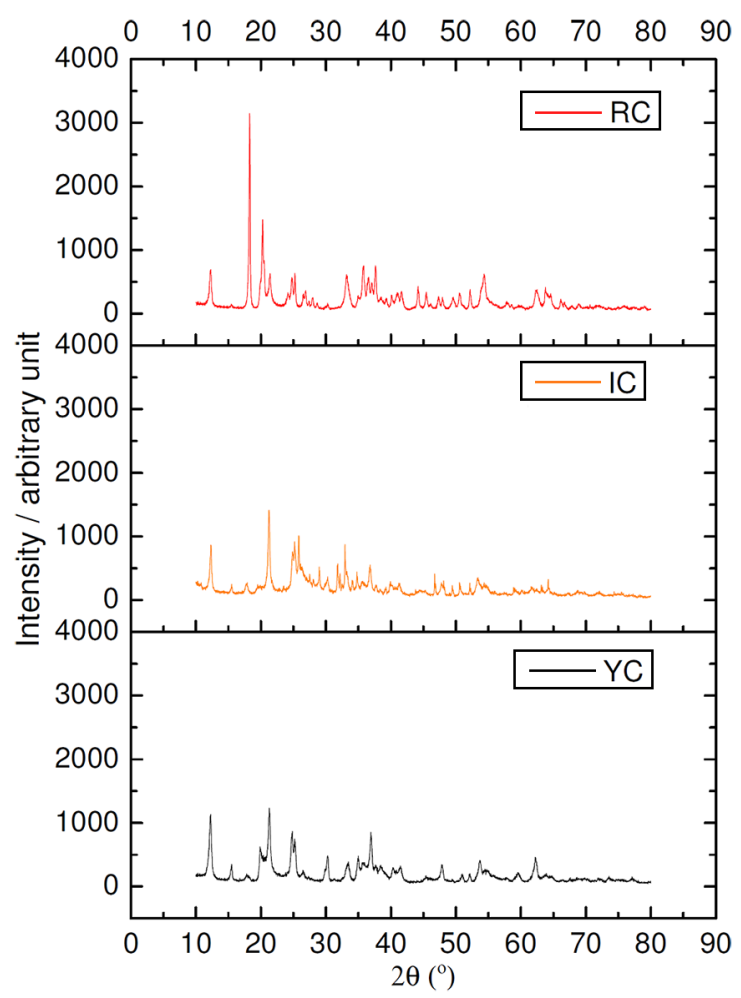

Figure 2. The X-ray diffraction data for the three types of clay. designed with the three calcined clays at temperatures of 680,760 , and $840^{\circ} \mathrm{C}$ and without calcining (WC). In some moulded proof-bodies with the addition of calcined clay, the compressive strength within the physical requirements parameters established in NBR $12653^{7}$ was equivalent to $75 \%$ of compressive strength (red line) attained by the reference mortar without the addition of calcined clay. Thus, these clays can be considered to be pozzolanic materials in accordance with the NBR $12653^{7}$ standard. For glass powder usage in partial replacement of the fine aggregate in cement composites, the results show that the increase in the compressive strength is a characteristic of materials with a good pozzolanic index ${ }^{8}$. In particular, red clay calcined at 680 to $840{ }^{\circ} \mathrm{C}$ presented pozzolanic behaviour in the pozzolanic activity index test. Moreover, intermediate clay

Table 5. Mass loss and pozzolanic activity index.

\begin{tabular}{|c|c|c|c|}
\hline $\begin{array}{c}\text { Sample } \\
\text { identification }\end{array}$ & $\begin{array}{c}\text { Mass loss } \\
(\%)\end{array}$ & $\Delta(\mathbf{m S} / \mathrm{cm})$ & $\begin{array}{c}\text { Pozzolanic } \\
\text { activity index }\end{array}$ \\
\hline YC.680.60 & 6.8 & 2.935 & High \\
\hline IC. 680.60 & 2.45 & 1.624 & High \\
\hline RC. 680.60 & 14.1 & 3.526 & High \\
\hline YC.760.60 & 6.6 & 2.595 & High \\
\hline IC.760.60 & 2.6 & 1.409 & High \\
\hline RC.760.60 & 14 & 3.883 & High \\
\hline YC. 840.60 & 6.4 & 2.054 & High \\
\hline IC. 840.60 & 3.1 & 0.940 & Moderate \\
\hline RC. 840.60 & 15.15 & 3.984 & High \\
\hline YC.680.120 & 6.95 & 2.885 & High \\
\hline IC. 680.120 & 2.95 & 1.699 & High \\
\hline RC. 680.120 & 14.55 & 4.064 & High \\
\hline YC.760.120 & 7.3 & 2.573 & High \\
\hline IC. 760.120 & 3.15 & 1.304 & High \\
\hline RC.760.120 & 15.3 & 3.869 & High \\
\hline YC. 840.120 & 7.4 & 1.584 & High \\
\hline IC. 840.120 & 3.4 & 0.795 & Moderate \\
\hline RC. 840.120 & 15.2 & 3.823 & High \\
\hline
\end{tabular}

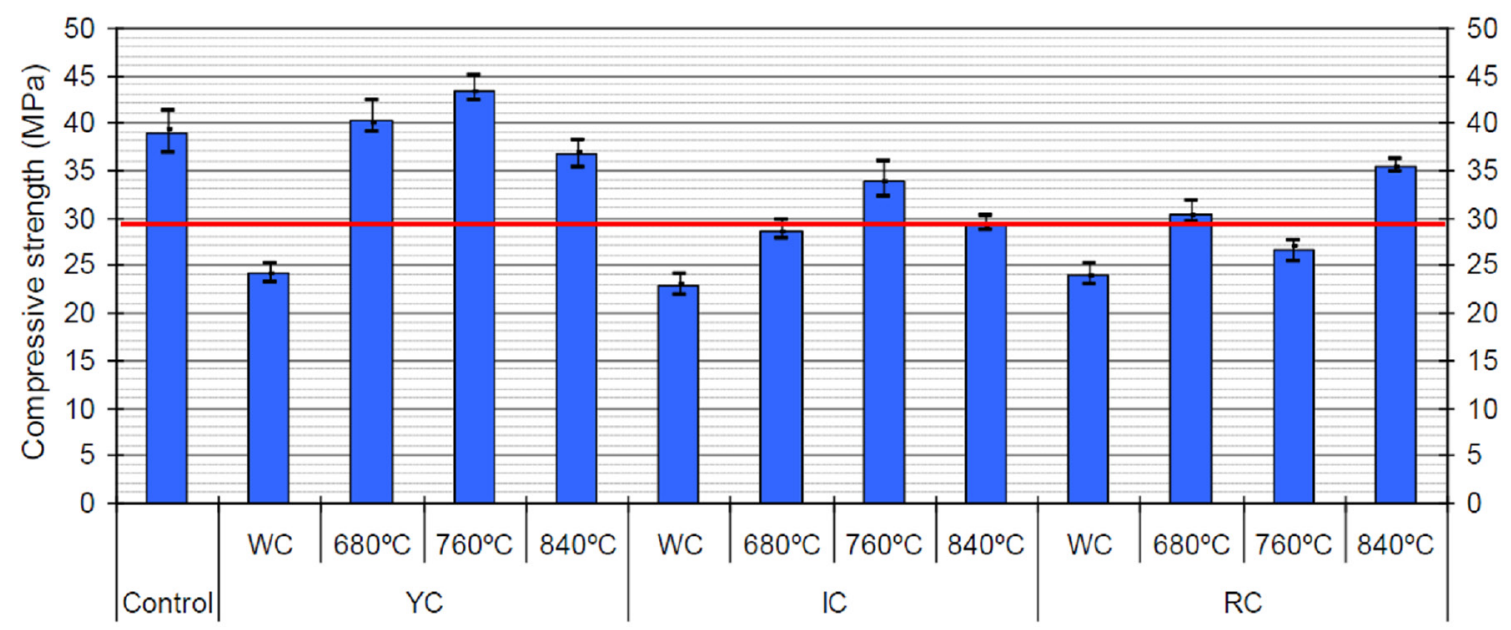

Figure 3. Pozzolanic activity index of cement. 
calcined at $760{ }^{\circ} \mathrm{C}$ presented pozzolanic behaviour in the pozzolanic activity index test.

\section{Conclusions}

This paper shows that the residual clay from the phosphate mining process has chemical and physical characteristics similar to the characteristics of known pozzolans. Calcined residual clays presented as pozzolanic materials using the electrical conductivity method in a saturated solution of calcium hydroxide, and the calcination process increases the pozzolanic activity index of cement. According to the tests performed, yellow clay presented as a effective pozzolan.

\section{References}

1. Santos RLC, Sobral LGS and Araújo RVV. Produção de fosfato no Brasil: complexo de mineração de tapira / fosfertil. Contribuição técnica do Centro de Tecnologia Mineral, Ministério da Ciência e Tecnologia, Coordenação de Metalurgia Extrativa. In: Anais do $19^{\circ}$ Encontro Nacional de Tratamento de Minérios e Metalurgia Extrativa -ENTMME; 2002; Recife, Brasil. Rio de Janeiro: CETEM; 2002.

2. Luxan MP, Madruga F and Saavedra J. Rapid evaluation of pozzolanic activity of natural products by conductivity measurement. Cement and Concrete Research. 1989; 19(1):6368. http://dx.doi.org/10.1016/0008-8846(89)90066-5.

3. Associação Brasileira de Normas Técnicas-ABNT. NBR 5752. Materiais pozolânicos: determinação de atividade pozolânica com cimento Portland: índice de atividade pozolânica com cimento. Rio de Janeiro: ABNT; 1992.

4. Silva VM, Góis LC, Duarte JB, Silva JB and Acchar W. Incorporation of ceramic waste into binary and ternary soil-

\section{Acknowledgements}

The authors thank Fundação da Amparo à Pesquisa do Estado de Minas Gerais (in English, Foundation for Research Support of the State of Minas Gerais), Conselho Nacional de Desenvolvimento Cientifico e Tecnológico (in English, National Council for Scientific and Technological Development), and Coordenação de Aperfeiçoamento de Pessoal de Ensino Superior and Centro Federal de Educação Tecnológica de Minas Gerais (in English, Federal Center for Technological Education of Minas Gerais) for financial support and scientific initiation scholarship.

cement formulations for the production of solid bricks. Materials Research. 2014; 17(2):326-331. http://dx.doi.org/10.1590/ S1516-14392014005000014.

5. Ribeiro DV, Labrincha JA and Morelli MR. Potential use of natural red mud as pozzolan for Portland cement. Materials Research. 2011; 14(1):60-66. http://dx.doi.org/10.1590/S151614392011005000001.

6. Hildebrando EA, Souza JAS, Angelica RS and Neves RF. Application of bauxite waste from Amazon Region in the heavy clay industry. Materials Research. 2013; 16(6):1418-1422. http://dx.doi.org/10.1590/S1516-14392013005000145.

7. Associação Brasileira de Normas Técnicas - ABNT. NBR 12653. Materiais pozolânicos - especificação. Rio de Janeiro: ABNT; 1992.

8. Miranda EJP Jr, Bezerra HJCL, Politi FS and Paiva AEM. Increasing the compressive strength of Portland cement concrete using flat glass powder. Materials Research. 2014; 17(Suppl 1):45-50. http://dx.doi.org/10.1590/S1516-14392014005000058. 